\title{
Exploring Literacy In Our Own Backyard: Increasing Teachers' Understanding of Literacy Access through Community Mapping
}

Kathy R. Fox

University of North Carolina, Wilmington, foxk@uncw.edu

Follow this and additional works at: https://digitalscholarship.unlv.edu/jpme

\section{Repository Citation}

Fox, Kathy R. (2014) "Exploring Literacy In Our Own Backyard: Increasing Teachers' Understanding of Literacy Access through Community Mapping," Journal of Praxis in Multicultural Education: Vol. 8: No. 2, Article 1.

DOI: $10.9741 / 2161-2978.1071$

Available at: https://digitalscholarship.unlv.edu/jpme/vol8/iss2/1

This Article is protected by copyright and/or related rights. It has been brought to you by Digital Scholarship@UNLV with permission from the rights-holder(s). You are free to use this Article in any way that is permitted by the copyright and related rights legislation that applies to your use. For other uses you need to obtain permission from the rights-holder(s) directly, unless additional rights are indicated by a Creative Commons license in the record and/ or on the work itself.

This Article has been accepted for inclusion in Journal of Praxis in Multicultural Education by an authorized administrator of Digital Scholarship@UNLV. For more information, please contact digitalscholarship@unlv.edu. 


\section{Introduction}

A cloud of dust surrounds a now dirt-yellow school bus Wednesday as it makes a three-point turn in a Baldwick County community nestled in a pocket of the county rarely seen by visitors or many locals. Through the dust, one can see a single-wide mobile home with a missing window and bed sheets for curtains, several cars parked in its front lawn. It's a neighborhood that several students from United Elementary School call home. The dust causes a few coughs from the teachers on the bus who were taking a community mapping tour of where some of their students live and to partially experience what some of their youngest children go through as part of their regular routine before they even start their day at school.

This excerpt of a local news story highlighted one principal's attempt to acquaint the teachers with the community of their children (Rodriguez, 2007). Prior to the school year, on the prep days so often used for organizational tasks such as calendar and school handbook issues, the staff members instead rode the school bus route. Once back at the school, they debriefed what they had learned about the families they served. Many of these teachers were experienced in the classroom and some were long-time residents of the county. The bus route, however, helped connect-or situate - the school in the larger community.

In this example teachers and administrators acknowledged that in order to best serve the needs of the child the teacher must put her/himself in the role of a learner, actively seeking ways to understand the lived experiences of the child. This article reports on a four-year action research project that examined the literacy community of children as reported by their own teachers. It describes the process used by in-service teachers to discover community literacy resources from a hands-on approach through a process called community literacy mapping. It reports the findings from the teachers' action research and discusses how they have used this information since conducting the project. Teachers were enrolled in graduate courses in literacy and in most cases taught in the school of the children whose community literacy resources they mapped. Up until this point the teachers may have felt that they knew their children well. In most cases, a positive rapport existed between the teachers, parents, grandparents and/or caregivers. However teachers sometimes may have felt uninformed about the community life outside of the school, including what types of literacy resources families were tapping into and how they maintained access to the resources.

Findings from this action research project revealed that when teachers took on the lens of a community literacy mapper, their collective results showed a great divide of resources in the communities. At times, teachers discovered 
surprising resources that they had not realized existed. Other times they were surprised by the contrast in resources, how a child's neighborhood had a marked disparity of literacy resources from that of the school facility. Still, another finding was the difference among age groups...that while there might be a relative wealth of activities and materials for one target age this significantly dropped off for other age groups, as if not only the need for but also the desire for literacy opportunities had a cut-off age.

The objective of the article is to encourage teachers to first investigate the communities they wish to educate...to become more aware of resources that exist and the creative ways that families make use of resources, albeit limited in many areas. Secondly teachers are encouraged by example to implement strategies to augment literacy resources and access in areas where needed.

\section{Theoretical Perspective}

A teacher may feel as if she has a strong and positive relationship with a child; however, this is often based on the child as a student member of the classroom. What may be missing is the perspective of the child as a member of a dynamic family unit situated within a community, of which the school is only one aspect. While some parents are physically involved in the classroom, others might be visible only for conferences and school wide events. Still others are the unknown group...they may sign permission forms and complete school distributed paperwork, but otherwise are invisible and unacknowledged at the school site (Epstein, 2010, 1983). What is important to recognize is that even the less visible parents have a stake hold in the education of their children while expressing it in various ways (Heath, 1983).

The goal of increasing parent involvement in the school is often addressed through school-based programs, many of which consist of classes and workshops for parents on teacher led topics (Amstutz, 2000). Benefits from such programs include increased parent knowledge on the proposed topic as well as the more subtle effect of mainstream school discourse, or knowledge about "how schools work" (Cummins, Brown \& Sayer, 2007; Author, 2010). In a study of $1^{\text {st }}$ grade family involvement, parent visibility at the school level added to their children's feelings of self-esteem, higher attendance rates, and more support in homework and other literacy events at both the school and home settings. However, as in many cases, the rate and engagement of parents depended on the engagement and consistency of the teacher's outreach to parents (Nistler \& Maiers, 2001).

A less talked about element of parent involvement is the teachers' and school personnel's lack of visibility in the homes and communities of the families. This shift is relatively recent, differing from just a few decades ago when many teachers lived near the school they taught, may have grown up in the 
school community, and had more intimate knowledge of the children, their extended families and the community as a whole. Recent incentive programs encourage education students to return to their home communities once they have received their credentials. Tuition subsidies and scholarships encourage high school students to consider teaching as a career and require graduates to teach in the state for a specified time period. 'Grow your own' strategies, such as North Carolina's Teaching Fellows Program (http://www.teachingfellows.org/) and Oklahoma's Teacher Shortage Employment Incentive Program (TSEIP) (http://www.okhighered.org/tseip/) Beginning teachers may find it especially difficult to teach in rural areas (Hines \& Mathis, 2007; Lemke, 1994; Little, 2011), in spite of these and other types of incentives, such as bonuses, housing subsidies, loan forgiveness, restaurant discounts and increased status. The key may be in community educational and cultural programs that go beyond the school day a teacher and require the effort of a coordinated school-community (Collins, 1999).

When teachers take on a learner's stance to examine the existing knowledge in the community, family literacy resources can be seen as an additive component to a school curriculum (Cummins, Brown \& Sayers, 2007). Documenting additive community resources is one way to shake up the deficit myth that low income and/or minority language and culture families live in a vacuum with little to no understanding or support for academics (Heath, 1983; Jiménez, Smith, \& Teague, 2009; Neuman \& Celano, 2001; Spindler, 1982). It reveals that the resources that do exist are often unknown to teachers, thus not recognized as valid resources that already exist and can be included in the curriculum (Moll, Gonzalez, Greenberg \& Velez, 2011).

An additional consideration is the so-called "faucet theory" which refers to the variations in opportunities within and outside of school boundaries, particularly in the summer and other break periods (Entwistle, Alexander, \& Olson, 1997). During school hours teachers are engaged with children and provide access to the school resources. After the school day, particularly during weekend and summer hours, not only do teachers disconnect with the children and their families, including community resources and facilities, but also school resources are untapped, turned off, dry up. School personnel may be unaware of the negative bi-directional effect of having resources locked up in the school facility, further disenfranchising the home and community with the imposed school resource boundary. The faucet effect can affect the relationship between the teachers and their students. Access to resources, such as the public library, computer, internet and other print sources, may be taken for granted by the teachers who may not realize how central the school resources are for some communities (Celano \& Neuman, 2010). A bidirectional lack of use and communication is created--teachers are disengaged and uninformed about the 
community and children and parents are disengaged from the school.

Making gaps in resources more visible can help participating teachers understand areas where their awareness and advocacy is most needed. It can also reveal hidden resources that teachers can make better known across the school and community. To help alleviate what Heath (2010) called the "elusive....achievement of equity in schooling, family time, and community organizational life-all of which stimulate and reward literacy" (p. 31) is the goal of this research, situated in the backyards, neighborhoods, community sites and events where teachers teach and students live outside the traditional school site.

\section{Methodology}

\section{Setting and Participants}

A 4-year study was designed to examine teachers' knowledge of community resources for children's and families' literacy development. The study was centered in the professional development community surrounding a university in southeastern United States. Renowned for its beaches, the area is also known for its history, including pre-Revolutionary and Civil War events, and early civil rights movements. Situated in a coastal agriculture belt, surrounded by rural counties, the immediate university area is often considered more urban and metropolitan. The county has both a traditionally diverse racial makeup (79\% White, $15 \%$ African American) and has recently become home to a large number of immigrants, primarily from Latin America (5\%), but also from eastern European and African countries (US Census 2010). Many cultural and ethnic communities have developed, some thriving more than others. Residents may live in exclusive brick homes just a couple of blocks away from others living in decaying buildings, crowded trailer parks and subsidized housing projects.

The university plays an important role in the area's development, and at any one time 13,000 students are residents of the city. The area's racial makeup is quite different from that of the university. Of the university population, $87 \%$ are white, and 13\% are listed as combined minority (Just the Facts, 2011). The university contributes the $2^{\text {nd }}$ highest number of teachers to the state.

The participating teacher researchers were enrolled in graduate literacy courses at the university. The mapping exercise was part of the final practicum course, wherein the students were required to tutor a child (Kindergarten-12 grade) for a minimum of 10 hours outside of the school day. Teachers in this study worked in some capacity in the schools while attending graduate school in the areas of language, literacy and curriculum development.

The geographical area in the study included an approximate 75 miles radius of the university from where teachers commuted. Urban, suburban, historic 
tourist-oriented and rural are labels used to describe areas within the study. All areas mapped were in the professional development system of the university, where school districts supported out students in their pre-service training and the university likewise offered graduate level and non-credit classes as continuing credit for in-service teachers.

\section{Data Collection}

A qualitative methodological approach was taken, with the adult learners being involved in a research in a meaningful context intending to solve real-world issues. Because the project involved in-service teachers conducting action research at community sites the methodology protocol was particularly important to establish (Green \& Harker, 1981). The participants first read models of community mapping programs and home visit protocols in professional literature (Jimenez, et.al, 2009; Neuman \& Celano, 2001; Nistler \& Maiers, 1999; Rodriguez, 2007). They also surveyed community maps completed by teachers in prior classes from nearby school communities.

Teachers were provided with blank tables modified to fit research goals from previous models in the literature on community mapping (See Sample Tables 1-5). The information required to complete the tables guided what teachers examined, including data on language, environmental print, community support systems and technology access. A written summary component following the data collection encouraged teachers to reflect on the effect of the resource distribution on their particular child, or "tutee."

As teachers set out to map a child's community in terms of literacy resources they were encouraged to conceive of their mapping area as a child would see it...from the front step of home to the classroom door. What route did the school bus take? If you were the child's parent in what areas would you most likely shop? Does the family drive a personal or public vehicle to school? Or does the child walk to school, and if so, with whom? Using what routes? Did the free print resources (in both signage and free media) reflect the language of the community? What print was made available? To what audience were these materials intended and to what group were less made available? What community events were advertised? To what community? Were there any communities ignored or invisible in the public and/or private outreach?

The teachers' maps generally encompassed an area of 3 miles or less. In urban and suburban areas even this small of an area proposed a challenge in able to "map it all", as visual overload and density of stores and shops became evident. Other teachers chose to expand the mapping area as they followed rural bus routes, worrying about "nothing to see" on a rural farm road. 
Some teachers paired up to enter communities, often asking the university researcher if she thought it would be "safe" to enter the school neighborhood on weekends or after school. To assuage these real fears, it was recommended that teachers were accompanied by someone (i.e., a classmate or family member) in order to assist with counting, photographing, and other forms of documentation. In any case, the old adage of two sets of eyes being better than one was employed.

In most cases, teachers related that the actual data collection took approximately 2-4 hours to complete. They then organized their data, added components that could be found either online or in school/community literature (e.g. school demographics, library circulation), and uploaded photographs to the document. Finally, they wrote a summary of their findings for their particular mapping area. These documents were submitted electronically in order to be shared in class for whole group analysis.

Over the course of several class sessions, teachers one by one shared their community mapping results. The reporting was done by neighborhood, starting with the area closest to the university and continuing to the more rural regions, still within one to two hour's drive of the university. This important step helped reveal the diversity of resource distribution in our professional development system, where the teachers all worked and lived. Without this very public discussion it would be difficult for the participants to actually see how just a matter of blocks or the long established community characteristics could make such a difference in terms of literature, technology, free and not-so-free access to literacy. The written summaries that accompanied each student's map were used to prompt teachers' reflections on what they learned from the experience. Teachers summarized both the wealth of resources in some areas and the gaps in others in graphic form through a whole group discussion. Finally teachers reflected on what measures could be taken to advocate for a more equal and just distribution of resources... who were the contact personnel to make these recommendations to, what steps could be taken in the short term and what were more long term decisions to address. Throughout the exercise, both individually and whole group, an additive approach was encouraged... what did we learn that we can share with others in our school community to promote a more authentic community literacy perspective?

\section{Results}

As mapping results were shared visually in class trends and contrasts emerged. Surprise registered around the room as teachers' misconceptions regarding availability and disparity of resources were raised. Following are examples that exemplify the trends and contrasts found in the results. 


\section{Result 1: Abundance of materials for some, dearth of materials for others}

Maps from the urban area revealed that materials were in abundant supply in chain used book stores and discount stores, often called 'dollar stores'. However these literacy materials-picture books, games, word search books, coloring books - were geared for the young, elementary age child. Resources for an older elementary, middle school or beginning high school age child were limited. The exceptions were magazines targeted at pre-teen and teen girls. One teacher wrote:

In the same shopping center was a bargain store. I did not expect the store to have very many titles for children or young adults, however I was pleasantly surprised. I tallied 131 children's titles and 19 young adult titles. There was a wide variety of picture books, chapter books and informational books. There were also several coloring and activity books for younger children. Excluding the coloring and activity books, the rest of the books were located in several large bins in the central aisle of the store. The books were mixed in with adult titles so they were not easily located. There were about 4 coloring books and 3 activity books located on the toy aisle.

Another teacher wrote:

It seems that my tutee has a wealth of stores to choose from within a mile radius of his house. I saw many individuals walking as I drove (many times) the same few blocks looping around this particular community. It seemed that walking was a pretty common occurrence as compared to what I have been accustomed to closer to my home. Unfortunately, very few of these nearby stores have a wide selection of adolescent novels; and those stores which do offer such selections, are targeted mainly to girls. I only found a handful of books which my tutee ( $5^{\text {th }}$ grade boy) might find even remotely interesting to read in his spare time. I did, however, find many sources of teen fashion magazines and adult materials, most likely the kinds of reading materials my tutee would have to resort to.

Another teacher noted that while there were some materials for young adults the quality and variety were very different from those offered for younger children. While she noted that in this suburban area the discount chain store had a large book rack with overhead signs stating "Book Nook" to attract store patrons, the themes were very commercially driven:

When I went in to count books, I found it very interesting looking at the difference in book shelving. The full aisle of children's books was full of colors, topics, visuals, buttons to press and items to touch. When you turned and looked at the two sections of "teen" and "young reader" books all I saw were vampires and dark gloomy covers. Where does the 
stimulus go? At what age is it determined that you are "now only interested in these pop cultural items?"

Teachers were forced to reconcile that while they were thankful for having these low cost books at a setting they knew neighborhood families would be comfortable attending, they soon saw that the lack of structure and quality control of books in this setting made viewing bargain and used book stores as a dependable resource problematic.

\section{Result 2: Disconnect between the historic community with tourist attractions and the community at large, including the immigrant population}

Teachers discovered that what on the outside looked ideal could in actuality be very limiting. Our region has many historical sites, dating back to early Native American settlements and pre-Revolutionary War sites. School field trips to these sites are a normal part of elementary curriculum. The roadsides and local shops boasted emblems of historical events that happened nearby. Many sites offered free materials, such as historical maps, brochures containing folklore and coloring sheets. However, the community map revealed that many children had limited access and knowledge of local resources beyond what was offered through the school or church. One example came from a teacher who worked with a high school age student of refugee status from Viet Nam. This student, along with her family, was being supported through a local interfaith ministry. Housing, clothing, food, and other essentials are addressed through the ministry and community services. The student had limited knowledge of cultural literacy resources beyond the school or church. Visual borders delineated her community from that of the historic, more tourist oriented community.

We pass Governor's Palace on the way to pick up our tutees. There are cute shops, beautiful gardens, and historical monuments around the tourist attraction. We make a left onto George Street, right in front of the Palace. It's shortly after that when the scenery changes. We make a right at the Police Department. There are no more cute shops or tourist attractions. Instead you will find a handful of bargain stores and run down gas stations. Abandoned buildings, apartments, old houses, factories, warehouses, bars, and churches are what you will find within walking distance from our tutees' home.

In her written summary the teacher questioned what real or perceived borders were dividing the community, barring the historical and cultural tourist attractions from the low income areas nearby. Living and working in the area for her lifetime, and even attending the church that sponsored the refugee community, she had not previously been aware of this divide. 
The hardest concept for me to grasp is the fact that so much could be offered to these refugees if they walked the few blocks into the historic district. I'm not sure if they realize how much is available to them, or if they don't feel they are entitled to it. The historic downtown area offers so many learning experiences that were presented to me as a child, whether though elementary school field trips, church outings, or with friends and family. In having this eye opening experience, I hope to share with the tutors that continue to work with these refugees the importance of sharing the natural learning experiences around us to each other. For example, the historical homes tour, the industry museum, and the governor's palace are just a few learning experiences within walking distance. Another opportunity is the science and nature lessons that could be taught with the rivers within such close proximity.

\section{Result 3: Differentiation of materials by zip code}

Teachers discovered a marked differentiation of literacy materials and access among communities with stores offering one type of literacy resource in one neighborhood and a different amount, array and standard of literacy resources in another. This was evident in some rural areas that were dependent on a small local market for groceries and supplies. A teacher wrote:

The only grocery store within the area is called Raymonds [sic] Grocery. It is only opened on weekdays from 8:00-5:00 pm, and on Saturdays from 8:00-1:00 pm. There was only one newspaper outside, USA Today. As I walked up and down the aisles, I was surprised that there were no magazines or books! Even near the checkout counter, there was nothing.

Perhaps more surprising was the range of materials in the same chain stores serving different communities. Teachers began to see that store distribution of literacy materials and access was dependent on perceived economic levels of patrons. However, in summaries teachers questioned the assumption that literacy resources would appear as superfluous to all patrons in any one particular economic level. One teacher, who lived in a beach community approximately 15 miles from her tutee, reflected on the differences in her community stores and those of the young high school girl she tutored living in the more urban area:

The bargain store was my last stop, and I was sure they would have some books to count. To my surprise they had the least amount. There were only 5 books for children (4 Disney books for girls and 1 about Scooby Doo.) There were 15 Crossword/ Word Search books, 50+ birthday cards, and two coupon papers.

No books for young adolescents! 
I thought about this on my drive home. I could have sworn there were more books at the same bargain store down the street from my house. So I went to take a look. There was a whole aisle full of books for children and adolescents, crossword puzzles, and cookbooks (by people from the Food Network). Then I went into the chain grocery store next to the bargain store. There was half an aisle dedicated to magazines and books, and more magazines could be found on stands at the checkout center. I couldn't help but find reading material in these stores. In the stores by my tutee's house I was searching and still coming up short. The problem of limited choices persisted and was delineated according to geographic and perceived income levels.

\section{Result 4: Target audience: To whom are the literacy resources and environmental print directed?}

Free literacy resources and environmental print tended to target the adult population. In the urban area, because the university was central to the downtown area, signs and resources were geared to the young adult consumer. One teacher discovered that her tutee, who she knew was on free and reduced lunch subsidies, lived in subsidized low income housing in the same complex as university students. In her summary she wrote:

The "neighborhoods" these children are familiar with are a far cry from what my definition of a "neighborhood" would have been in elementary school. I now understand why during a tutoring session my tutee said that he almost always "hangs with college kids." I have lived here for ten years and yet saw things today that I can honestly say I'd never noticed before. I noticed who was going in and out of the stores I was exploring, the number of people simply sitting in their cars in the parking lot, the difference between the people wandering the aisles of Target and those who milled through Marshall's, and the men sitting along the side of the road, holding a sign, and asking for help from the community. After today I can honestly say I have a much better grasp of the environment from which my students come to me every morning and to where they return in the afternoons. Many of my children come from low income housing, small townhouses off diminutive - almost invisible - side streets, and apartment buildings I had always associated with transient college kids.

Another teacher commented on the signage in her school community. Nothing but real estate signs and real estate ad boxes. No newspapers or public service materials were available. Every billboard advertised food...sometimes with waitresses displaying drinks. My seven year old son, 
along with me for helping to count materials, pointed out that the Hooters girl had changed on the large billboard as you enter the city. First of all I was surprised he knew the word "Hooters" and especially that he would recognize the girl on the sign. Really, what does this say about our city?

Another teacher wrote about the same issue but in another more suburban area: When driving around I was shocked by the number of food establishments in such a small one mile radius. Almost a third of the business signs seen were restaurant related and all of the logos that I noticed were food related (McDonalds, Chick-Fill-A, Wendy's...)These food signs were the ones that stood out compared to the rest due to either size, color, lights, or all. If that is where the stimulus is when driving by, why wouldn't that be where the people are drawn to? Most of the signs were very drab in color or design.

Urban areas were found to have the most commercial resources for print, as would have been expected. In some cases there were too many sign and materials to count accurately. However gaps in audiences were discovered. One teacher wrote in her summary:

Trying to count and read all the signs on Market Street sent me into overload mode. There are over 300 signs including advertisements, logos, lawyer billboards and offices, other business office signs, and street signs. The majority of these signs are in good condition, which I found shocking. I am amazed how safe the quiet neighborhood of Fern Hill seems and how less than a mile on Market St. feels extremely unsafe to me.

\section{Results 4: Discrepancy in library access}

Another finding that teachers were surprised about was in library access across schools and communities. Comparing one school's library hours to another's revealed that the power held by a few individuals at the school affected many children's literacy access. In one school library in a downtown urban area a teacher reported:

I called Williams Middle School and spoke with the media center coordinator. She was extremely helpful and ran an inventory sheet to tell me exactly how many books were in the library. I was delighted to find there are 16,305 books available to students. There are 7 computers available to student in the media center as well.

This teacher reported that the school library was open for one and a half hours after school dismissal. One school in a more affluent suburban neighborhood reported that the elementary and middle school libraries were available to children 
all day, as long as they had a hall pass from the classroom teacher. Other schools reported an unlimited check out, with children being allowed to go to the library whenever classwork was complete. However other schools had a one book per week policy.

A rural school, where the nearest local public library was more than twenty miles from the school, had the strictest check out policies. On the day of the mapping exercise the $6^{\text {th }}$ grade tutee was not allowed to go with her class to the school library because she owed fines for an overdue book. The teacher discovered the fines were from much earlier in the year. The child's censure from the library was ongoing until the fine was paid. The teacher reflected that the school library was her most likely resource for reading materials:

Araceli lives in a very rural area that does not offer resources to support her literate growth. Her school is the only library anywhere nearby, and that is eight miles away from her home. The school library is open only during school hours, so evening, weekend, and summer visits with her family are not possible. The nearest public library is in Ballance, a twenty minute drive from her home. Because there is a grocery store in the town of Ridge Point, her family probably has no reason to travel outside of the general area very often. It would seem logical that trips to the public library would be unlikely ventures. Araceli and her family would have to work at, or at least make a big effort, to go out of their way to provide literate experiences for her outside of her school-related events.

Public libraries symbolize access to much more than books. Teachers may assume that children who do not have access to technology in their homes can find it in public libraries or by utilizing the school media resources. Mapping results showed however, that particularly in the case of rural communities, access to technology was very limited. Usage was structured to fit daytime patrons, as hours generally followed the traditional work day. In many instances, particularly in rural areas, libraries were closed on weekends. Time on computers was typically structured to allow for the maximum amount of people to use the media, rather than any sustained period of study. One teacher noted it was barely enough time to log on and begin a search, much less start reading or taking notes. In Araceli's case, her closest library allowed for patrons to sign up for 15 minutes at a time on the computer. Table 6: School and Community Library Access shows the limited time of circulation at Araceli's school and public libraries. 
Table 6 School and Community Library Access

\begin{tabular}{|c|c|c|c|c|}
\hline Setting & $\begin{array}{c}\text { Number of } \\
\text { books }\end{array}$ & $\begin{array}{l}\text { Condition } \\
\text { of books }\end{array}$ & $\begin{array}{c}\text { Number of days } \\
\text { open }\end{array}$ & $\begin{array}{l}\text { Number of } \\
\text { computers }\end{array}$ \\
\hline $\begin{array}{l}\text { Middle } \\
\text { School } \\
\text { Library }\end{array}$ & 12,000 & Excellent & $\begin{array}{l}\text { M-F during } \\
\text { school year } \\
\text { Open for } \\
\text { circulation } 7: 45 \\
-8: 15 \text { or } 11: 30 \\
-12 \text { with hall } \\
\text { pass }\end{array}$ & $\begin{array}{l}3 \text { in library } \\
1 \text { student } \\
\text { computer lab }\end{array}$ \\
\hline $\begin{array}{l}\text { Public } \\
\text { Library }\end{array}$ & 27,000 & $\begin{array}{l}\text { Above } \\
\text { average }\end{array}$ & $\begin{array}{l}\text { M\&T 9- } \\
\text { 8,W\&Th 9-6, } \\
\text { F\&S 9-5 }\end{array}$ & $\begin{array}{l}10 \\
\text { Time limit of } 15 \\
\text { minutes per } \\
\text { setting if needed }\end{array}$ \\
\hline
\end{tabular}

\section{Result 5: Surprising resources found}

To teachers' welcomed surprise, resources were found in areas not traditionally recognized by the school. An array of community services, afterschool programs, as well as stores, shops and salons provided free $\mathrm{Wi}$-Fi and a myriad of children's books and magazines. In some businesses it was found that the foyers would be full of free reading material and in multiple languages. Educational games and toys were also spotted, sometimes for clients' children and other times seemingly there for the children of employees.

Teachers in urban and suburban areas were surprised to find that chain drug stores and coffee shops were often dependable sources for literacy. One $8^{\text {th }}$ grade teacher reported:

My tutee lives very close to Market Street. The closest resources for him would be the Port City Coffee, which has free Wi-Fi, if he had a laptop. There were current newspapers he could access. There is a wall of books for customers to read while in the coffee house. However most of these books are adult literature and some would be appropriate for young adult readers, but not children. The best place for my tutee to find literature would be the chain drugstore near Columbus Ave. The drugstore offers many children's and young adult titles. There were magazines geared towards younger children and plenty of appropriate magazines geared toward young adults. There were also word search activity books, novels, 
board books, travel activity books, and greeting cards with print. There were also newspapers near the front of the store.

Nail salons were found to be a dependable source of literacy access in all geographic areas. They offered magazines, children's books, and often educational toys for children of patrons to play with.

Second hand stores were also a surprising resource for literacy materials. In every area teachers found that stores in this category offered books and other literacy materials. In some cases the local second hand store had more books than any other store in the vicinity. One teacher remarked, "I now know I can recommend this shop to families for good quality books at a very reasonable price. I'm also going to let other teachers at my school know about it." The dependability of titles and condition of texts varied, as no store buyer would be able to suggest an age appropriate title for the parent. Instead suitable titles would be dependent on the kindness of donations.

In the historic tourist oriented community one dentist had a lending library, used by his patients for check out between and during visits. This dentist serviced patients of all ages, and his book shelf included books at all levels. The lending service was on an honor basis, with a sign out sheet made available. His office was located centrally and known to locals as a literacy resource.

Free wireless access was offered at some surprising sources. One donut chain shop had unlimited free Wi-Fi. They had large booths and offered coloring sheets with puzzles and word searches as well. A regional gas station chain offered a seating area and free Wi-Fi. The area was clean, family friendly and spacious.

In all areas some restaurants offered children's menus and crayons. Some had write-on table cloths. One family pizza shop had white-boards for messages in the bathrooms.

Environmental print varied greatly among the communities. Teachers reported having too many signs to count while at the same time commenting that most signs in all areas were in good condition. In rural areas teachers commented on the local nature of environmental print. A teacher commented:

The visibility of signs in Ridge Point can be clearly seen riding in a car, a bike or walking. In the two and a half mile radius that I researched, I saw a total of 113 community oriented signs, all of which were in good condition. While I found that while the area lacks in providing literacy to its community, the most available resource for children and young adults is the signs that line the streets. The signs are an excellent way for children to associate reading with everyday life.

Another teacher commented on the local pride shown in the signs in her rural community. She noticed that on her tutee's bus route she would see artistically decorated mailboxes and signs naming family farms. In some cases 
these signs and logos signified multiple generations of the same family living in close proximity. Other signs advertised local goods, arts and crafts. Often signs used humor and symbolic language to draw attention to their notice, such as the hog farm that pictured a family of hogs artfully carved and painted on the mailbox frame. She noted that in all these cases the signs were in good condition and were in prominent display at the end of driveways or hanging from posts and trees.

One tourist oriented beach community had a popular walking trail. The environmental print on the signs was not only informative but family friendly, marking the trail and giving information for pet-owners. Local school children had designed the artwork making it visually appealing and easy to read.

The purposeful mapping of the community led participants to develop a greater understanding of resources--often unseen by the schools--that actively supported children's literacy.

\section{Conclusion and Implications for Action}

In all cases teachers' maps were seen as valued evidence of the multiple view of community literacy. As Neuman \& Celano (2001) noted, rural and urban areas of poverty showed fewer marketed or free materials than suburban areas. However even affluent areas, such as tourist-oriented areas, varied greatly in the amount of environmental print, free and public access, and availability of resources.

Access to technology was found in libraries but numbers and hours of access for families with school age children were reduced from what teachers expected. Library hours served the non-working population, and after-school hours limited computer use to short time allotments. Often computers were segregated by age, with only a small amount of computers accessible to "children".

One previously held assumption that was subsequently dispelled was the lack of elementary and young adolescent appropriate level literacy materials in affluent areas. When literacy materials were available they seemed to target seniors or young professionals. Most prevalent were real estate brochures and sales materials, and street signs generally were adult oriented and included adult content. In a few cases, children's messages were found in environmental print. What was offered as "family friendly" most often advertised food. Very few public safety or other types of community content were available in commercial signage.

Discussions occurred regarding who makes the decisions about the ways people of different income levels spend their money, the marketability of materials, and ultimately the right to literacy resources. Teachers remarked on the wealth of materials in one chain store in a more suburban area and absolute lack 
of materials in the same chain store in a lower economic neighborhood. One student remarked that she "couldn't help but find literacy materials" in her neighborhood grocery store, but that in the same store, in the lower income neighborhood of her student, there were no literacy resources for sale or as free publications. She said:

In the stores by Noe's house I was searching and still coming up short. This got me thinking. I guess when people are living in poverty and barely making enough money to buy the necessities they do not spend a lot of money on books. So dollar stores take this into consideration when stocking their shelves. The people living in Noe's neighborhood have very limited access to print. They would have to make a special trip to buy a book or magazine. It helps explain why there is a Head Start center in the middle of her neighborhood. [The center] is a small, brick school house, enclosed by a tall, chain link fence. Thankfully, places like this are available for young children.

The absence of literature for pre-teens and young adults was also noted, which could be taken as a statement that people in those age bracket were not consumers of literature or print materials.

The only store anywhere near Angie's home is just beyond a 1.5 mile radius. The only reading material that can be found in the store are the weekly County Post and Ridge Point Chronicle newspapers, business cards taped to the check-out counter, and the signs advertising the cost of menu items from the grill. There are no child-friendly reading materials. Teachers also pondered the effect that these marketing decisions had on the community. A teacher working in a rural area wrote:

This study made me think and wonder a few things: What do the findings from this assignment tell us? Is there a correlation to reading and the literacy community around an individual? If you visited an area that has higher reading scores should you expect to see more stimuli for young people? Would you find more opportunities for reading?

This teacher has begun to question the assumption that her tutee and her parents would never choose to buy a book. She saw the hardship it would place on them to find a book - a bus trip to another area of town for any appropriate books or magazines. For her younger cousins, the Salvation Army offered discount materials. The problem persisted however that her choices would be limited to what others had donated.

In all cases teachers' maps were seen as valued evidence of community literacy. While each area had a distinctive character and ethos, teachers were able to develop an overall map or "bird's eye view" of literacy resources in our area. They were also able to take this perspective to uncover gaps in resources---some geographical and some according to age groups and language distinctions. 


\section{Implications}

This project documented the work of in-service teachers who bridged the divide by entering into the neighborhoods, community centers and other support agencies of the children they teach. It revealed gaps in some areas and surprising resources in others. Whole class summative comments showed that knowledge translated to advocacy - measures were explored of how better to inform teachers of the support services that do exist and how to value these services in the schools. After viewing the maps overtime teachers have made a to-do list for the school and community. Each teacher is encouraged to respond to the question: What can I do at my school to bridge the gaps in literacy access. In some cases the teacher were looking for ways to add literacy access, while in other cases it would be to use her or his school community as either a model or a resource for less resource-rich areas.

An action plan for greater school library access was one of the first areas developed. In some cases school personnel were addressed regarding more open circulation policies. One participant developed a plan for her school, situated in a high income with high levels of parent involvement, to "adopt a school library." The school buddied with a public school located only 4 miles away but which had less parent involvement that impacted the school library hours. Parent library volunteers from still another school met with the media specialist at a neighboring school to help develop a training module for parents to implement more open library access.

Perhaps the most significant outcome has been in addressing the faucet effect caused by summer break gaps in library access. For the first time this summer grant funding has been awarded to keep the school libraries open for children in neighborhood schools. The funding includes a stipend for personnel to facilitate the program and to advertise the service to the community. Figures $1 \&$ 2 demonstrate the outreach to families by the use of the school marquee advertising summer library access. 
Journal of Praxis in Multicultural Education, Vol. 8, No. 2 [2013], Art. 1

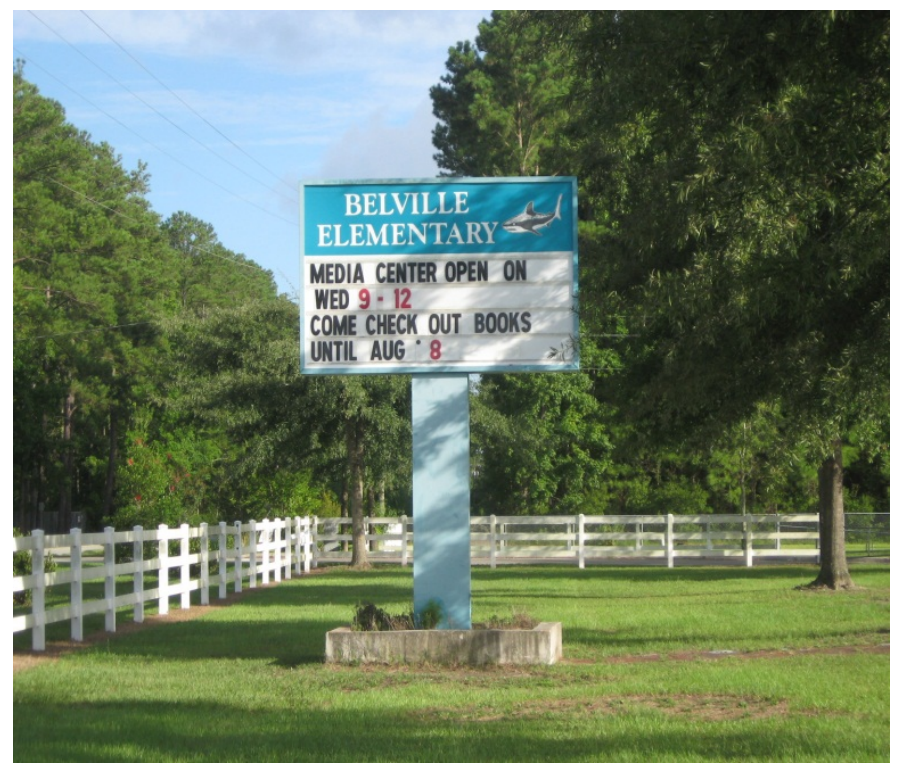

Figure 1: Library access

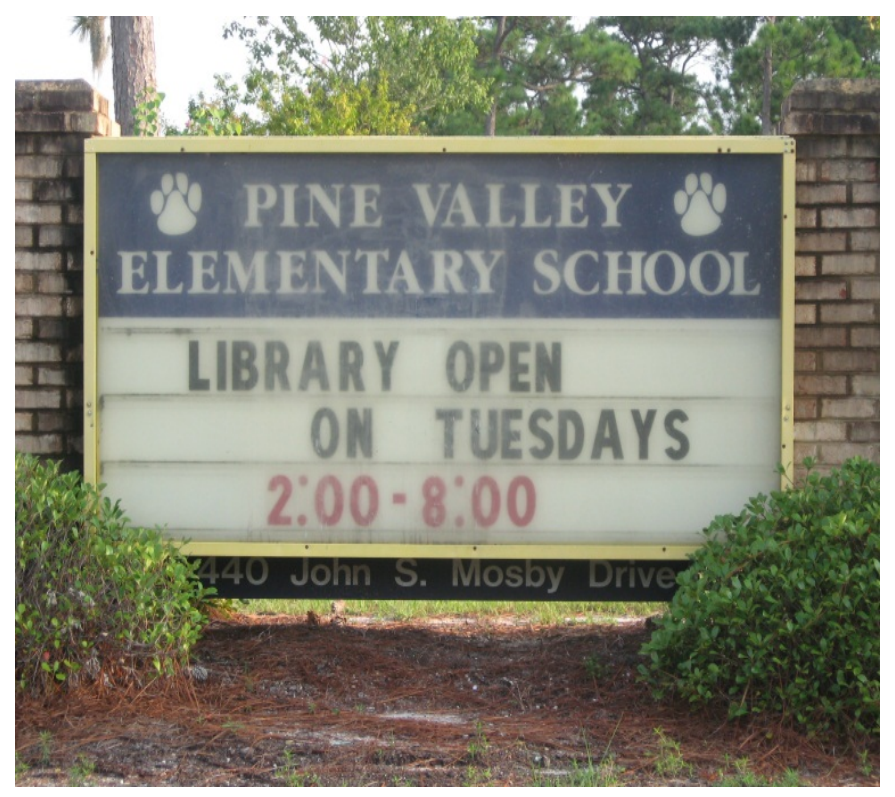

Figure 2: Library access 
Believing that knowledge is power, they have encouraged other teachers and administrators at their schools to find ways to learn about the community. A resource guide was developed by teachers. One section listed sources for free $\mathrm{Wi}$ $\mathrm{Fi}$, areas for open literacy (i.e. quiet reading, writing, and electronics), lending libraries, and stores selling literacy materials, including both used and new books. Another section was designed to showcase local community and school events, some ongoing (international pen pals to military service personnel) and some annual events (such as Muffins for Moms in a Kindergarten class). Parent oriented events were coded according to Epstein's Parent Involvement Scale (2010), showing the range of activities or events. The resource guide offered information about local access, while at the same time showing a comparison between communities by juxtaposing points of access from one community to the next on the same page, thereby showing gaps in resources. A sample page of this guide is included here in Table 7: Sample Pages from Community Resource Guide.

Table 7 Sample Pages from Community Resource Guide

\begin{tabular}{|l|l|l|l|}
\hline $\begin{array}{l}\text { Type of parent } \\
\text { activity } \\
\text { (Epstein, 2010) }\end{array}$ & $\begin{array}{l}\text { Specific resource/event/ } \\
\text { approximate date or } \\
\text { time of year }\end{array}$ & Location & Description \\
\hline $\begin{array}{l}\text { Collaborating with } \\
\text { the community } \\
\text { May, school day }\end{array}$ & $\begin{array}{l}\text { Muffins for moms- } \\
\text { Land school }\end{array}$ & $\begin{array}{l}\text { Moms invited for } \\
\text { mother's day } \\
\text { brunch }\end{array}$ \\
\hline $\begin{array}{l}\text { Learning at school } \\
\text { and home }\end{array}$ & $\begin{array}{l}\text { "How Things Work" } \\
\text { Fair }\end{array}$ & $\begin{array}{l}\text { K-5 Ogland } \\
\text { Elementary }\end{array}$ & $\begin{array}{l}\text { Students } \\
\text { voluntarily create } \\
\text { posters at home } \\
\text { which explain } \\
\text { how something } \\
\text { works (ex. The life } \\
\text { cycle of a } \\
\text { butterfly) and } \\
\text { bring in to school } \\
\text { to share what they } \\
\text { learned. }\end{array}$ \\
\hline $\begin{array}{l}\text { Health and } \\
\text { Welfare }\end{array}$ & $\begin{array}{l}\text { Girls on the } \\
\text { Run/STRIDE }\end{array}$ & $\begin{array}{l}\text { Toppsville and } \\
\text { Prader }\end{array}$ & $\begin{array}{l}\text { Training for a 5K } \\
\text { with teacher } \\
\text { volunteers and } \\
\text { team building }\end{array}$ \\
\hline
\end{tabular}




\begin{tabular}{|c|c|c|c|}
\hline & & Elementary & $\begin{array}{l}\text { exercises (Race } \\
\text { in fall and spring) }\end{array}$ \\
\hline $\begin{array}{l}\text { Volunteering } \\
\text { Collaborating with } \\
\text { the community }\end{array}$ & Spring Fling & $\begin{array}{l}\text { Castle Land } \\
\text { Elementary }\end{array}$ & $\begin{array}{l}\text { Fundraiser for } \\
\text { school- games- } \\
\text { silent auction- } \\
\text { open to the public }\end{array}$ \\
\hline $\begin{array}{l}\text { Collaborating with } \\
\text { the community }\end{array}$ & Donuts for Dad & $\begin{array}{l}\text { K- Castle Land } \\
\text { Elementary }\end{array}$ & $\begin{array}{l}\text { Dads invited for } \\
\text { father's day } \\
\text { breakfast }\end{array}$ \\
\hline $\begin{array}{l}\text { Collaborating with } \\
\text { the community }\end{array}$ & Father-Daughter Dance & $\begin{array}{l}\text { Castle Land } \\
\text { Elementary }\end{array}$ & $\begin{array}{l}\text { Fathers invited for } \\
\text { a dance with their } \\
\text { daughters }\end{array}$ \\
\hline $\begin{array}{l}\text { Collaborating with } \\
\text { the community }\end{array}$ & $\begin{array}{l}\text { Mother Son Kickball } \\
\text { Game }\end{array}$ & $\begin{array}{l}\text { Castle Land } \\
\text { Elementary }\end{array}$ & $\begin{array}{l}\text { Mothers invited } \\
\text { for dinner and } \\
\text { kickball game } \\
\text { with sons }\end{array}$ \\
\hline $\begin{array}{l}\text { Collaborating with } \\
\text { the community }\end{array}$ & Lunch with a Veteran & $\begin{array}{l}\text { Bolevar } \\
\text { Elementary }\end{array}$ & $\begin{array}{l}\text { Veterans invited to } \\
\text { have lunch with } \\
\text { students }\end{array}$ \\
\hline $\begin{array}{l}\text { Volunteering } \\
\text { Collaborating with } \\
\text { the community }\end{array}$ & Fall Family Fun Night & $\begin{array}{l}\text { Bolevar } \\
\text { Elementary }\end{array}$ & $\begin{array}{l}\text { Students and } \\
\text { Parents involved } \\
\text { in various } \\
\text { activities (games, } \\
\text { competitions, } \\
\text { etc...) }\end{array}$ \\
\hline $\begin{array}{l}\text { Health and } \\
\text { Welfare }\end{array}$ & Turkey Trot & $\begin{array}{l}\text { Bolevar } \\
\text { Elementary }\end{array}$ & $\begin{array}{l}\text { Donation of food } \\
\text { and the last day } \\
\text { everyone that } \\
\text { wants to } \\
\text { participate, walks } \\
\text { laps together } \\
\text { outside }\end{array}$ \\
\hline $\begin{array}{l}\text { Health and } \\
\text { Welfare }\end{array}$ & Super Kids Day & $\begin{array}{l}\text { Bolevar } \\
\text { Elementary }\end{array}$ & $\begin{array}{l}\text { Olympics outside, } \\
\text { all grade levels } \\
\text { and everyone is } \\
\text { invited }\end{array}$ \\
\hline
\end{tabular}




\begin{tabular}{|l|l|l|l|}
\hline $\begin{array}{l}\text { Learning at School } \\
\text { and Home }\end{array}$ & Thorp Science Night & $\begin{array}{l}\text { Bolevar } \\
\text { Elementary } \\
\text { students } \\
\text { participate in } \\
\text { various science } \\
\text { experiments }\end{array}$ \\
\hline Communicating & Night of the Notables & $\begin{array}{l}\text { Bolevar } \\
\text { Elementary }\end{array}$ & $\begin{array}{l}\text { Students } \\
\text { demonstrate their } \\
\text { knowledge of a } \\
\text { chosen person of } \\
\text { interest }\end{array}$ \\
\hline $\begin{array}{l}\text { Collaborating with } \\
\text { the community }\end{array}$ & Spot Festival & $\begin{array}{l}\text { Prader County } \\
\text { Schools }\end{array}$ & $\begin{array}{l}\text { School employees, } \\
\text { Police department, } \\
\text { and Fireman } \\
\text { volunteer al duties } \\
\text { at Spot Festival } \\
\text { for two days, and } \\
\text { portion of } \\
\text { proceeds are given } \\
\text { back to } \\
\text { community }\end{array}$ \\
\hline
\end{tabular}

A bus tour of the school community is planned for another school group prior to the next year's school opening. Classes offering graduate level credit on the topic of parent involvement and community literacy are being considered as a part of the core curriculum. Classes providing continuing education units (CEU's) for teachers on the topic of family literacy are in demand. These and other small wins are important for creating greater shared knowledge between the parents, children and teachers. 


\section{References}

Amstutz, D. (2000). Family literacy: Implications for public school practice. Education and Urban Society, 32, 207-220.

Author (2010).

Celano, D. and Neuman, S. (2010). Roadblocks on the information highway. Educational Leadership, 68(3), 50-53.

Collins, Timothy. "Attracting and Retaining Teachers in Rural Areas." Dec. 1999. ERIC Digest. Retrieved from www.eric.ed.gov/ERICDocs/data/ ericdocs2sq1/content_storage_01/0000019b/80/16/0c/c0.pdf.

Cummins, J. Brown, K. \& Sayers, D. (2007). Literacy, Technology, and Diversity: Teaching for Success in Changing Times. Boston: Pearson.

Epstein, J. (2010). Partnerships then and now. New directions. Research-Based Programs of Family and Community Involvement for Student Success. Transforming ESEA: Helping Public Schools Improve: A Public Discussion. Washington, D.C. June 29, 2010. Retrieved from http://www.edaccountability.org/Joyce\%20Epstein\%20Powerpoint\%20Presentati on\%20FEA\%20June\%2029, \%202010\%20Symposium.pdf.

Epstein, J., Becker, H., and Hollifield, J. (Eds.) (1983). Study of Teacher Practices of Parent Involvement: Results from Surveys of Teachers and Parents. Baltimore, Maryland: Johns Hopkins University.

Green, J.L., \& Harker, J. (Eds.), (1981). Multiple perspective analyses of classroom discourse: Methods and issues. Norwood, NJ, Ablex.

Heath, S.B. (1983). Ways with words: Language, life, and work in communities and classrooms. Cambridge, England: Cambridge University Press.

Heath, S.B. (2010). Family literacy or community learning? Some critical questions on perspective. In Fisher, D. \& Dunsmore, K., Eds. Bringing Literacy Home pp. 15-41. New Jersey: International Reading Association.

Hines, D. \& Mathis, K. (2007). Regional and specific incentives for teacher recruitment and retention. Retrieved from http://www.dpi.state.nc.us/docs/intern-research/reports/incentives-trr.pdf

Jiménez, R.T., Smith, P.H., \& Teague, B.L. (2009). Transnational and community literacies for teachers. Journal of Adolescent \& Adult Literacy, (53)1, 1626.

Just the Facts. Retrieved from http://www.uncw.edu/aboutuncw/aboutJustthefacts.html

Lemke, June C. "Teacher Induction in Rural and Small School Districts.” March 1994. ERIC Digest. Retrieved from http://www.eric.ed.gov/ERICDocs/data/ericdocs2sq1/content_storage_01/0 000019b/80/1 5/86/d7.pdf.

Little, S. (6/8/2011). Senate budget would eliminate NC Teaching Fellows. Daily Tarheel. Retrieved from 
http://www.dailytarheel.com/index.php/article/2011/06/senate_budget_wo uld_eliminate_nc_teaching_fellows.

Moll, L., Gonzalez, N., Greenberg, J. \& Velez, C. Funds of Knowledge. Retrieved from

www.usc.edu/dept/education/CMMR/FullText/LuisMollHiddenFamilyRes ources.pdf.

Neuman, S. \& Celano, D. (2001). Access to print in low-income and middle income communities. Reading Research Quarterly, (36)1, 8-26.

Nistler, R. \& Maiers, A. (1999). Effects of a 2-year study of a family literacy program in an urban first-grade classroom. Education and Urban Society, (31), 108-126.

Rodriguez, J. (2007). Bus tour adds context for teachers: Educators experience children's path. The Myrtle Beach Sun News and www.MyrtleBeachONline.com. (September 20, 2007).

Spindler, G.D. (1982). Doing the ethnography of schooling: Educational anthropology in action. New York: Holt, Rinehart and Winston. In Heath, S.B. (2010). Family literacy or community learning? Some critical questions on perspective. In Fisher, D. \& Dunsmore, K., Eds. Bringing Literacy Home p.17. New Jersey: International Reading Association.

US Census State and County Quick Facts. Retrieved from http://quickfacts.census.gov/qfd/states/37/37129.html 
Table 1 Demographics

\begin{tabular}{|c|c|c|c|c|c|}
\hline $\begin{array}{c}\text { Communit } \\
\mathrm{y}\end{array}$ & $\begin{array}{c}\text { Total } \\
\text { population }\end{array}$ & $\begin{array}{l}\text { Elementary } \\
\text { population }\end{array}$ & $\begin{array}{l}\% \\
\text { Minority }\end{array}$ & $\%$ Poverty & $\begin{array}{l}\% \text { Educational } \\
\text { attainment (from } \\
\text { US Census data) }\end{array}$ \\
\hline $\begin{array}{l}28401 \\
\text { Housing } \\
\text { Project }\end{array}$ & $\begin{array}{l}24,031 \\
256 \text { units } \\
401 \text { families } \\
675 \text { residents }\end{array}$ & $\begin{array}{l}7 \%+\text { or }- \\
\text { Birth-K=48 } \\
6-12 \text { years } \\
=37\end{array}$ & $\begin{array}{l}51 \% \\
95 \% \\
\text { African } \\
\text { America } \\
n\end{array}$ & $\begin{array}{l}\text { Close to } \\
100 \% \\
\text { Avg. } \\
\text { income } \\
\text { Family of } \\
3= \\
\$ 10,208\end{array}$ & $\begin{array}{l}\text { Less than HS } \\
14.5 \% \\
\text { HS Degree } \\
18.5 \% \\
2 \text { Year Degree } \\
6 \% \\
4 \text { Year Degree } \\
10.29 \% \\
\text { Graduate Degree } \\
4.68 \%\end{array}$ \\
\hline
\end{tabular}

Table 2 Number of places selling children's and youth's literacy resources (Children: 0-11 years Youth 12+ years)

\begin{tabular}{|l|c|}
\hline \multicolumn{1}{|c|}{ Children } & 0 \\
\hline Bookstores & 0 \\
\hline Drugstores & 0 \\
\hline Grocery stores & 1 \\
\hline Bargain stores & 1 \\
\hline Corner stores & 0 \\
\hline Other stores & 1 \\
\hline Children's stores & 0 \\
\hline Total & 3 \\
\hline
\end{tabular}




\begin{tabular}{|l|c|}
\hline \multicolumn{1}{|c|}{ Youth } & \\
\hline Bookstores & 0 \\
\hline Drugstores & 0 \\
\hline Grocery stores & 0 \\
\hline Bargain stores & 1 \\
\hline Corner stores & 0 \\
\hline Other stores & 1 \\
\hline $\begin{array}{l}\text { Youth oriented } \\
\text { stores }\end{array}$ & 1 \\
\hline \multicolumn{1}{|c|}{ Total } & 3 \\
\hline
\end{tabular}


Table 3 Literacy resources found in community

(Children: 0-11 years Youth 12+ years)

\begin{tabular}{|c|c|c|c|c|c|}
\hline Store name & Type & $\begin{array}{l}\text { Wi-Fi } \\
\text { access }\end{array}$ & $\begin{array}{c}\text { Children's } \\
\text { Titles }\end{array}$ & $\begin{array}{l}\text { Youth } \\
\text { titles }\end{array}$ & Type \\
\hline \multirow[t]{2}{*}{ Wal-Mart } & Everything & No & 350 & 40 & Books \\
\hline & & & 5 & 14 & Magazines \\
\hline \multirow{2}{*}{$\begin{array}{l}\text { Lowe's } \\
\text { Food }\end{array}$} & Grocery & No & 65 & 0 & Books \\
\hline & & & 0 & 0 & Magazines \\
\hline \multirow[t]{2}{*}{ Dollar Store } & Bargain & No & 96 & 0 & Books \\
\hline & & & 0 & 0 & Magazines \\
\hline \multirow[t]{2}{*}{ Game Stop } & Electronic & No & 0 & 0 & Books \\
\hline & & & 0 & 2 & Magazines \\
\hline \multirow[t]{2}{*}{ Scotchman } & $\begin{array}{l}\text { Gas/grocery/snack } \\
\text { bar }\end{array}$ & Yes & 4 & 15 & Books \\
\hline & & & 4 & 15 & Magazines \\
\hline $\begin{array}{l}\text { Krispy } \\
\text { Kreme }\end{array}$ & Donut Shop & Yes & 1 & 0 & $\begin{array}{l}\text { Menu with } \\
\text { activities }\end{array}$ \\
\hline \multirow{2}{*}{$\begin{array}{l}\text { Extreme } \\
\text { Nails }\end{array}$} & Salon & Yes & 12 & 2 & Books \\
\hline & & & 1 & 6 & Magazines \\
\hline $\begin{array}{l}\text { Hansom } \\
\text { Park }\end{array}$ & $\begin{array}{l}\text { City park and nature } \\
\text { center }\end{array}$ & No & 60 & 22 & $\begin{array}{l}\text { Books, } \\
\text { brochures }\end{array}$ \\
\hline
\end{tabular}


Table 4 Number and condition of signs in community

\begin{tabular}{|c|c|c|c|c|c|}
\hline Street & Community & Business & Logos & $\begin{array}{c}\text { \% Good } \\
\text { condition }\end{array}$ & $\begin{array}{c}\text { \% Poor } \\
\text { condition }\end{array}$ \\
\hline 292 & 31 & see below & 13 & $99 \%$ & $1 \%$ \\
\hline
\end{tabular}

- I counted 18 "business signs" dealing with land for sale; items to buy that were not traditionally established businesses.

- There were a total of 139 established businesses in the area.

- Of the 139 businesses I put them into subgroups to help get an idea of the area:

- 35 were restaurants or fast foods, 20 were health/beauty related, 10 were auto related, 5 were rental/storage spaces, and 12 were banks. The remaining 57 were miscellaneous. 
Table 5 Sources for literacy or participating in literacy (i.e. places for reading, access to media, etc.)

\begin{tabular}{|c|l|l|l|l|}
\hline Setting & $\begin{array}{c}\text { Number of } \\
\text { seats/spaces }\end{array}$ & Condition & $\begin{array}{c}\text { Number of } \\
\text { days and } \\
\text { time open }\end{array}$ & $\begin{array}{c}\text { Number of } \\
\text { computers/materi } \\
\text { als available }\end{array}$ \\
\hline After school care: & Under 20 & Fair & $6 / 2: 45$ & 25 \\
$\begin{array}{l}\text { Mustard } \\
\text { Seed } \\
\text { Kids \& } \\
\text { Company }\end{array}$ & 50 & Fair & $6 / 2: 45$ & None \\
\hline Nature park & $\begin{array}{l}\text { Under 5 under } \\
\text { canopy }\end{array}$ & Good & $\begin{array}{l}7 \text { days until } \\
\text { dusk }\end{array}$ & $\begin{array}{l}\text { Informational } \\
\text { print }\end{array}$ \\
\hline
\end{tabular}


Table 7 Sample Pages from Community Resource Guide

\begin{tabular}{|c|c|c|c|}
\hline $\begin{array}{l}\text { Type of parent } \\
\text { activity } \\
\text { (Epstein, 2010) }\end{array}$ & $\begin{array}{l}\text { Specific resource/event/ } \\
\text { approximate date or } \\
\text { time of year }\end{array}$ & Location & Description \\
\hline $\begin{array}{l}\text { Collaborating with } \\
\text { the community }\end{array}$ & $\begin{array}{l}\text { Muffins for moms- } \\
\text { May, school day }\end{array}$ & $\begin{array}{l}\mathrm{K} \text {-Castle } \\
\text { Land school }\end{array}$ & $\begin{array}{l}\text { Moms invited for } \\
\text { mother's day } \\
\text { brunch }\end{array}$ \\
\hline $\begin{array}{l}\text { Learning at school } \\
\text { and home }\end{array}$ & $\begin{array}{l}\text { "How Things Work" } \\
\text { Fair }\end{array}$ & $\begin{array}{l}\text { K-5 Ogland } \\
\text { Elementary }\end{array}$ & $\begin{array}{l}\text { Students } \\
\text { voluntarily create } \\
\text { posters at home } \\
\text { which explain } \\
\text { how something } \\
\text { works (ex. The life } \\
\text { cycle of a } \\
\text { butterfly) and } \\
\text { bring in to school } \\
\text { to share what they } \\
\text { learned. }\end{array}$ \\
\hline $\begin{array}{l}\text { Health and } \\
\text { Welfare }\end{array}$ & $\begin{array}{l}\text { Girls on the } \\
\text { Run/STRIDE }\end{array}$ & $\begin{array}{l}\text { 3-5 Ogland, } \\
\text { Toppsville and } \\
\text { Prader } \\
\text { Elementary }\end{array}$ & $\begin{array}{l}\text { Training for a } 5 \mathrm{~K} \\
\text { with teacher } \\
\text { volunteers and } \\
\text { team building } \\
\text { exercises (Race } \\
\text { in fall and spring) }\end{array}$ \\
\hline $\begin{array}{l}\text { Volunteering } \\
\text { Collaborating with } \\
\text { the community }\end{array}$ & Spring Fling & $\begin{array}{l}\text { Castle Land } \\
\text { Elementary }\end{array}$ & $\begin{array}{l}\text { Fundraiser for } \\
\text { school- games- } \\
\text { silent auction- } \\
\text { open to the public }\end{array}$ \\
\hline $\begin{array}{l}\text { Collaborating with } \\
\text { the community }\end{array}$ & Donuts for Dad & $\begin{array}{l}\text { K- Castle Land } \\
\text { Elementary }\end{array}$ & $\begin{array}{l}\text { Dads invited for } \\
\text { father's day } \\
\text { breakfast }\end{array}$ \\
\hline $\begin{array}{l}\text { Collaborating with } \\
\text { the community }\end{array}$ & Father-Daughter Dance & $\begin{array}{l}\text { Castle Land } \\
\text { Elementary }\end{array}$ & $\begin{array}{l}\text { Fathers invited for } \\
\text { a dance with their }\end{array}$ \\
\hline
\end{tabular}




\begin{tabular}{|c|c|c|c|}
\hline & & & daughters \\
\hline $\begin{array}{l}\text { Collaborating with } \\
\text { the community }\end{array}$ & $\begin{array}{l}\text { Mother Son Kickball } \\
\text { Game }\end{array}$ & $\begin{array}{l}\text { Castle Land } \\
\text { Elementary }\end{array}$ & $\begin{array}{l}\text { Mothers invited } \\
\text { for dinner and } \\
\text { kickball game } \\
\text { with sons }\end{array}$ \\
\hline $\begin{array}{l}\text { Collaborating with } \\
\text { the community }\end{array}$ & Lunch with a Veteran & $\begin{array}{l}\text { Bolevar } \\
\text { Elementary }\end{array}$ & $\begin{array}{l}\text { Veterans invited to } \\
\text { have lunch with } \\
\text { students }\end{array}$ \\
\hline $\begin{array}{l}\text { Volunteering } \\
\text { Collaborating with } \\
\text { the community }\end{array}$ & Fall Family Fun Night & $\begin{array}{l}\text { Bolevar } \\
\text { Elementary }\end{array}$ & $\begin{array}{l}\text { Students and } \\
\text { Parents involved } \\
\text { in various } \\
\text { activities (games, } \\
\text { competitions, } \\
\text { etc...) }\end{array}$ \\
\hline $\begin{array}{l}\text { Health and } \\
\text { Welfare }\end{array}$ & Turkey Trot & $\begin{array}{l}\text { Bolevar } \\
\text { Elementary }\end{array}$ & $\begin{array}{l}\text { Donation of food } \\
\text { and the last day } \\
\text { everyone that } \\
\text { wants to } \\
\text { participate, walks } \\
\text { laps together } \\
\text { outside }\end{array}$ \\
\hline $\begin{array}{l}\text { Health and } \\
\text { Welfare }\end{array}$ & Super Kids Day & $\begin{array}{l}\text { Bolevar } \\
\text { Elementary }\end{array}$ & $\begin{array}{l}\text { Olympics outside, } \\
\text { all grade levels } \\
\text { and everyone is } \\
\text { invited }\end{array}$ \\
\hline $\begin{array}{l}\text { Learning at School } \\
\text { and Home }\end{array}$ & Thorp Science Night & $\begin{array}{l}\text { Bolevar } \\
\text { Elementary }\end{array}$ & $\begin{array}{l}\text { Parents and } \\
\text { students } \\
\text { participate in } \\
\text { various science } \\
\text { experiments }\end{array}$ \\
\hline Communicating & Night of the Notables & $\begin{array}{l}\text { Bolevar } \\
\text { Elementary }\end{array}$ & $\begin{array}{l}\text { Students } \\
\text { demonstrate their } \\
\text { knowledge of a } \\
\text { chosen person of } \\
\text { interest }\end{array}$ \\
\hline Volunteering & Spot Festival & $\begin{array}{l}\text { Prader County } \\
\text { Schools }\end{array}$ & $\begin{array}{l}\text { School employees, } \\
\text { Police department, } \\
\text { and Fireman }\end{array}$ \\
\hline
\end{tabular}




\begin{tabular}{|c|c|c|c|}
\hline $\begin{array}{l}\text { Collaborating with } \\
\text { the community }\end{array}$ & & & $\begin{array}{l}\text { volunteer al duties } \\
\text { at Spot Festival } \\
\text { for two days, and } \\
\text { portion of } \\
\text { proceeds are given } \\
\text { back to } \\
\text { community. }\end{array}$ \\
\hline $\begin{array}{l}\text { Learning at school } \\
\text { and home }\end{array}$ & Global Connections Day & $\begin{array}{l}\text { Toppsville } \\
\text { Elementary }\end{array}$ & $\begin{array}{l}\text { All students and } \\
\text { staff learn about } \\
\text { specific country or } \\
\text { culture with focus } \\
\text { on How to help } \\
\text { others (Pennies for } \\
\text { Polio) }\end{array}$ \\
\hline $\begin{array}{l}\text { Collaborating with } \\
\text { the community }\end{array}$ & $\begin{array}{l}\text { Spring and/or Winter } \\
\text { Concert }\end{array}$ & $\begin{array}{l}\text { Toppsville } \\
\text { Elementary }\end{array}$ & $\begin{array}{l}\text { All grades perform } \\
\text { various types of } \\
\text { music. }\end{array}$ \\
\hline $\begin{array}{l}\text { Volunteering } \\
\text { Collaborating with } \\
\text { the community }\end{array}$ & Spring/Fall Festival & $\begin{array}{l}\text { Toppsville } \\
\text { Elementary }\end{array}$ & $\begin{array}{l}\text { On Saturday, } \\
\text { teachers, parents } \\
\text { and students } \\
\text { participate in fun } \\
\text { activities. }\end{array}$ \\
\hline Volunteering & Volunteer Breakfast & $\begin{array}{l}\text { Toppsville } \\
\text { Elementary }\end{array}$ & $\begin{array}{l}\text { Teachers prepare } \\
\text { food and thank } \\
\text { parents for help! }\end{array}$ \\
\hline $\begin{array}{l}\text { Parent and teacher } \\
\text { involvement }\end{array}$ & $\begin{array}{l}\text { Fall Festival Bucket } \\
\text { Raffle }\end{array}$ & $\begin{array}{l}\text { K-5 Parkland } \\
\text { Elementary }\end{array}$ & $\begin{array}{l}\text { Each class donates } \\
\text { a "bucket" of } \\
\text { goodies and } \\
\text { students drop in } \\
\text { their } \$ 1 \text { raffle } \\
\text { tickets to win }\end{array}$ \\
\hline
\end{tabular}

\begin{tabular}{|l|l|l|l|l|}
\hline $\begin{array}{l}\text { After School } \\
\text { Programs: }\end{array}$ & Title & Provider & Dates/Times & Other \\
School Community & & & & \\
\hline
\end{tabular}




\begin{tabular}{|c|c|c|c|c|}
\hline setting & & & & \\
\hline $\begin{array}{l}\text { Samuels } \\
\text { Elementary }\end{array}$ & $\begin{array}{l}\text { Hillcrest } \\
\text { Reading } \\
\text { Program }\end{array}$ & $\begin{array}{l}\text { University \& } \\
\text { other grants }\end{array}$ & $\begin{array}{l}\text { Tues/Thurs } \\
\text { 2:30-4:30 } \\
\text { University } \\
\text { semester } \\
\text { schedule only }\end{array}$ & $\begin{array}{l}1-1 \text { tutoring } \\
\text { using Direct } \\
\text { Instruction }\end{array}$ \\
\hline Ogland Elementary & $\begin{array}{l}\text { After School } \\
\text { Program }\end{array}$ & $\begin{array}{l}\text { New Hansom } \\
\text { County }\end{array}$ & $\begin{array}{l}\text { Monday-Friday } \\
\text { 2:00-6:00 }\end{array}$ & $\begin{array}{l}\text { Set Schedule } \\
\text { daily } \\
\text { including } \\
\text { Group game, } \\
\text { Quiet time, } \\
\text { and outside } \\
\text { time. Snack } \\
\text { provided } \\
\text { daily. }\end{array}$ \\
\hline $\begin{array}{l}\text { Prader County } \\
\text { Schools }\end{array}$ & $\begin{array}{l}\text { Summer } \\
\text { Program }\end{array}$ & $\begin{array}{l}\text { Prader County } \\
\text { Parks and } \\
\text { Recreation }\end{array}$ & $\begin{array}{l}\text { 7:00-6:00 All } \\
\text { summer, } \\
\text { Monday -Friday }\end{array}$ & $\begin{array}{l}\text { Field trips } \\
\text { provided } \\
\text { weekly, } \\
\text { including } \\
\text { swimming, } \\
\text { movies, } \\
\text { public library } \\
\text { trips, etc. }\end{array}$ \\
\hline $\begin{array}{l}\text { Toppville } \\
\text { Elementary }\end{array}$ & $\begin{array}{l}\text { Dolphin } \\
\text { After-School } \\
\text { Program }\end{array}$ & $\begin{array}{l}\text { Dolphin } \\
\text { Program }\end{array}$ & 2:30-6:00 daily & $\begin{array}{l}\text { Flexible } \\
\text { schedule with } \\
\text { homework } \\
\text { time, Karate } \\
\text { instruction } \\
\text { two days a } \\
\text { week, outside } \\
\text { time, and } \\
\text { snack }\end{array}$ \\
\hline $\begin{array}{l}\text { Bolevar } \\
\text { Elementary }\end{array}$ & $\begin{array}{l}\text { No after } \\
\text { school care } \\
\text { on campus }\end{array}$ & & & \\
\hline $\begin{array}{l}\text { Bolevar } \\
\text { Elementary }\end{array}$ & $\begin{array}{l}\text { Libraries } \\
\text { open over the } \\
\text { summer }\end{array}$ & $\begin{array}{l}\text { State grant to } \\
\text { have libraries } \\
\text { open across }\end{array}$ & $\begin{array}{l}\text { Tuesday } 9-11 \\
\text { Thursday } 1-3\end{array}$ & $\begin{array}{l}\text { Once a month } \\
\text { crafts, read } \\
\text { alouds, }\end{array}$ \\
\hline
\end{tabular}




\begin{tabular}{|l|l|l|l|l|}
\hline & & the state & & $\begin{array}{l}\text { snack, and } \\
\text { book swap }\end{array}$ \\
\hline $\begin{array}{l}\text { Parkland } \\
\text { Elementary }\end{array}$ & $\begin{array}{l}\text { YMCA } \\
\text { afterschool } \\
\text { care }\end{array}$ & YMCA & Mon-Fri 2:30-6 & $\begin{array}{l}\text { Homework, } \\
\text { Free time and } \\
\text { snack } \\
\text { provided on } \\
\text { campus }\end{array}$ \\
\hline
\end{tabular}

